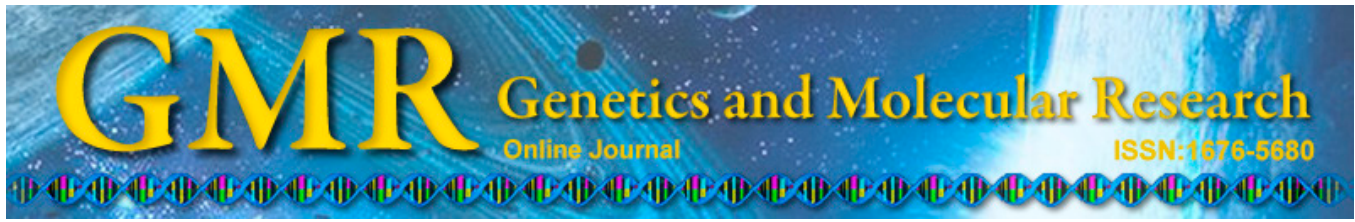

\title{
Prospective molecular markers for the identification of illegally traded angelsharks (Squatina) and dolphin (Sotalia guianensis)
}

\author{
L.H.O. Falcão ${ }^{1,2}$, M.A.A. Furtado-Neto ${ }^{1,2}$, R. Maggioni ${ }^{1}$ and V.V. Faria ${ }^{3}$ \\ ${ }^{1}$ Instituto de Ciências do Mar - LABOMAR, Universidade Federal do Ceará, \\ Fortaleza, CE, Brasil \\ ${ }^{2}$ Departamento de Engenharia de Pesca, Universidade Federal do Ceará, \\ Fortaleza, CE, Brasil \\ ${ }^{3}$ Departamento de Biologia, Universidade Federal do Ceará, Fortaleza, \\ CE, Brasil
}

Corresponding author: V.V. Faria

E-mail: vicentefaria@gmail.com

Genet. Mol. Res. 13 (4): 9710-9717 (2014)

Received May 21, 2014

Accepted October 6, 2014

Published November 24, 2014

DOI http://dx.doi.org/10.4238/2014.November.24.2

\begin{abstract}
Endangered angelsharks and a protected dolphin species are illegally traded in Brazil. In this study, we determined prospective molecular markers for detecting these species in the trade of angelshark carcasses and 'dolphin' eyeball amulets. We compiled publicly available as well as new and unpublished cytochrome $b$ (cyt $b$ ) DNA sequences for species involved in these trades. These sequences were digested in silico using restriction enzymes. We then described prospective polymerase chain reaction (PCR)-restriction fragment length polymorphism markers for distinguishing between protected species and the species whose trade
\end{abstract}


was legally allowed in these two trade groups. The prospective marker for identifying angelshark carcasses consists of cyt $b$ PCR and digestion by $B s t \mathrm{XI}, B s g \mathrm{I}, B s p \mathrm{MI}, B s r \mathrm{DI}$, and HaeII restriction enzymes. The prospective marker for identifying eyeball amulets consists of cyt $b$ PCR and digestion by ApoI, BtsI, HindII, BsaAI, BplI, and $S s p \mathrm{I}$ restriction enzymes. This is the first study to deposit in GenBank cyt $b$ sequences for the angelshark species Squatina argentina, Squatina guggenheim, and Squatina occulta. Moreover, the $S$. argentina haplotype is the first DNA sequence for this species deposited in GenBank.

Key words: Endangered species; Fishery product identification; Polymerase chain reaction-restriction fragment length polymorphism; Cytochrome $b$

\section{INTRODUCTION}

Fishery products are most commonly traded lacking key morphological features permitting species identification. Hence, it is often difficult to determine whether a particular product is from an endangered species (Bornatowski et al., 2013). For instance, two of the three species of angelsharks (genus Squatina) present off the southern coast of Brazil are forbidden from being captured or traded by Brazilian legislation because of their status as 'endangered species' (Instrução Normativa 5, May 2004). However, when traded as carcasses, it becomes difficult to determine whether any of these species, for which trade is prohibited, is included (Diário Catarinense, 2013; G1, 2013). Another example is the trade of 'dolphin' eyeball amulets in northern Brazil (Gravena et al., 2008). All cetacean fishing is banned in Brazil (Law 7.643, December 1987). However, eyeball amulet trade involves a dolphin species (Sotalia guianensis) and two species of common domestic animals with no trade limitations (pig and sheep), whose eyeballs are often fraudulently sold as Amazon river dolphin eyeball amulets (Gravena et al., 2008).

DNA sequences from the mitochondrial gene cytochrome $b$ (cyt $b$ ) are useful for identifying angelsharks from the southern coast of Brazil (Furtado-Neto and Carr, 2002) and dolphin species involved in trade in northern Brazil (Cunha et al., 2005; Gravena et al., 2008; Sholl et al., 2008). Therefore, direct sequencing of cyt $b$ can be used to determine whether endangered species are being traded. Another technique that is simpler and less expensive compared to DNA sequencing is polymerase chain reaction-restriction fragment length polymorphism (PCR-RFLP) (Mendonça et al., 2009). PCR-RFLP markers have been used with success in detecting frauds in the fishery trade (Espiñeira et al., 2009). In this study, we determined prospective cyt $b$ PCR-RFLP markers for detecting the presence of endangered or protected species in the trade of angelshark carcasses in southern Brazil and of eyeball amulets in the northern region of the country. We present cyt $b$ sequences for angelsharks and dolphin species.

\section{MATERIAL AND METHODS}

\section{Study subject and research strategy}

This study included two groups of species. One group consisted of the angelsharks 
from the southern coast of Brazil: Squatina guggenheim and S. occulta, whose capture and trade are prohibited nationwide, and S. argentina, for which capture and trade is allowed in Brazil. The other group studied included species used for the trade of 'dolphin' eyeball amulets in northern Brazil (Gravena et al., 2008): the dolphin S. guianensis, whose capture and trade is prohibited nationwide, and the domestic pig Sus scrofa and sheep Ovis aries. From a trade perspective, these two groups are referred to as 'angelshark' and 'eyeball amulet'.

For both groups, species for which capture and trade is prohibited in Brazil are referred to as 'protected' (protected species included S. guggenheim, S. occulta, and S. guianensis). In contrast, species for which capture and trade is allowed nationwide are referred to as 'commercial' species (commercial species included $S$. argentina, $S$. scrofa, and $O$. aries).

Our research strategy involved three main steps. First, we compiled cyt $b$ sequences for specimens in the two groups of species, including new and unpublished sequences for angelsharks and dolphins. Next, we digested each DNA sequence in silico using a computing tool and commercially available restriction enzymes. Finally, we evaluated the expected or theoretical profiles for each group in order to describe prospective PCRRFLP markers to distinguish between protected and commercial species from each of 'angelshark' and 'eyeball amulet' groups.

\section{DNA sequences}

We compiled available DNA sequences homologous to the initial portion of the mitochondrial cyt $b$ gene. New and unpublished sequences for the three angelshark species and the dolphin S. guianensis were described by Furtado-Neto (1998). One additional sequence from the river dolphin Sotalia fluviatilis described by this same author was also compiled for reference purposes. These sequences were deposited in GenBank. Next, all available cyt $b$ sequences for the two dolphin species, as well as domestic pig and sheep, were obtained from GenBank (http://www.ncbi.nlm.nih.gov/genbank/) (Table 1).

Table 1. Mitochondrial cytochrome $b$ DNA sequences (haplotypes) digested in silico for the determination of PCR-RFLP markers to distinguish between protected and commercial species from two groups.

\begin{tabular}{|c|c|c|c|c|c|c|}
\hline \multirow[t]{2}{*}{ Group/Species } & \multirow[t]{2}{*}{ Common name } & \multirow[t]{2}{*}{ Capture and trade status } & \multicolumn{2}{|c|}{ Newly deposited in GenBank* } & \multicolumn{2}{|c|}{ Obtained from GenBank } \\
\hline & & & Haplotypes & Specimens & Haplotypes & Specimens \\
\hline \multicolumn{7}{|l|}{ Angelshark } \\
\hline Squatina argentina & Argentine & Commercial & 1 & 3 & - & - \\
\hline Squatina guggenheim & Angular & Protected & 1 & 3 & - & - \\
\hline Squatina occulta & Hidden & Protected & 1 & 3 & - & - \\
\hline \multicolumn{7}{|l|}{ Eyeball amulet } \\
\hline Sotalia guianensis & Dolphin & Protected & 5 & 29 & 7 & 21 \\
\hline Sus scrofa & Pig & Commercial & - & - & 5 & 6 \\
\hline Ovis aries & Sheep & Commercial & - & - & 6 & 20 \\
\hline \multicolumn{7}{|l|}{ Additional species** } \\
\hline Sotalia fluviatilis & Dolphin & Protected & 1 & 1 & 3 & 6 \\
\hline
\end{tabular}

*DNA sequences obtained by Furtado-Neto (1998). **Included for reference and comparison purposes only. Angelshark DNA sequences were 362 bp long, while those for the eyeball amulet and additional species were 365 bp long. 


\section{Description of PCR conditions for sequences newly deposited in GenBank}

PCR was used by Furtado-Neto (1998) to amplify part of the mitochondrial DNA gene cyt $b$ (light strand primer L14724: 5'-CGA AGC TTG ATA TGA AAA ACC ATC GTT G-3'; heavy strand primer H15149: 5'-GCC CCT CAG AAT GAT ATT TGT CCT CA-3'; Irwin et al., 1991). Each PCR amplification was performed in $100-\mu \mathrm{L}$ reactions containing $2 \mu \mathrm{L}$ template DNA, $67 \mathrm{mM}$ Tris-HCl, $\mathrm{pH}$ 9.0, $9.94 \mathrm{mM} \beta$-mercaptoethanol, $2 \mathrm{mM}$ of each dNTP, $1.96 \mathrm{mM} \mathrm{MgCl}_{2}, 0.4 \mathrm{mM}$ of each primer, and 1-3 U AmpliTaq DNA polymerase (Perkin-Elmer, Waltham, MA, USA). Amplification was performed in a thermal cycler as follows: initial denaturation of $5 \mathrm{~min}$ at $95^{\circ} \mathrm{C}$, followed by 35 cycles of 1 min at $93^{\circ} \mathrm{C}, 1 \mathrm{~min}$ at $40^{\circ} \mathrm{C}$, and $30 \mathrm{~s}$ at $55^{\circ} \mathrm{C}$, and $2 \mathrm{~min}$ at $72^{\circ} \mathrm{C}$, with a final extension for $10 \mathrm{~min}$ at $72^{\circ} \mathrm{C}$.

\section{GenBank accession numbers}

S. guianensis. EU022549.1; EU022547.1; EU022545.1; EU022548.1; EU022546.1; EF027038.1;EF027036.1;EF027034.1;EF027037.1;EF027035.1;DQ086827.1;EF488223.1; EF488221.1;EF488219.1; EF488217.1;EF488222.1;EF488220.1; EF488218.1;EF488216.1; EF457552.1; EF027033.1.

S. fluviatilis. EF457551.1 (misidentified as S. guianensis in GenBank); EF027040.1; EF027039.1; DQ086828.1; AF084078.1; AF304067.1.

S. scrofa. AB015080.1; AB015078.1; AB015076.1; AB015081.1; AB015079.1; AB015077.1.

O. aries. JX235881.1; JX235879.1; JX235877.1; JX235875.1; JX235873.1; JX235871.1；JX235869.1；JX235867.1；JX235865.1；JX235863.1；JX235861；JX235859; JX235857.1; JX235855.1; JX235853.1; JX235851.1; JX235849.1; JX235847.1; JX235845.1; JX235843.1.

\section{Newly deposited in GenBank}

S. argentina. KJ879250, Rio Grande do Sul, Brazil, [N = 3]. S. guggenheim. KJ879251, Rio Grande do Sul [N = 3]. S. occulta. KJ879252, Rio Grande do Sul [N = 3].

S. fluviatilis. KJ879249, Amazonas [N = 1]. S. guianensis. KJ879244, Pará [N = 2], Ceará $[\mathrm{N}=8$ ], Bahia [ $=1]$, Rio de Janeiro [ $\mathrm{N}=4$ ], São Paulo [ $\mathrm{N}=5$ ], and Santa Catarina [ $\mathrm{N}=1]$; KJ879245, Ceará $[\mathrm{N}=2]$ and Rio de Janeiro [N =1]; KJ879246, Ceará $[\mathrm{N}=2]$; KJ879247, Bahia [N = 1]; KJ879248, São Paulo [N = 1] and Santa Catarina [N $=1]$.

\section{Sequence alignment}

All sequences were aligned and checked for homology. Those from GenBank that were not homologous to the initial portion of the cyt $b$ gene were excluded from the dataset. Sequences were then trimmed. The angelshark group dataset contained sequences that were $362 \mathrm{bp}$ long. The eyeball amulet group sequences were $365 \mathrm{bp}$ long. Both dataset sequences 
started at the first codon of the cyt $b$ gene. Each dataset was aligned using MEGA 5 (Tamura et al., 2011). After defining the dataset for each group, haplotypes for each species were identified using PAUP* (Swofford, 2000).

\section{In silico digestion}

Each haplotype was subjected to in silico digestion by 173 commercially available restriction enzymes using Restriction Mapper (http://www.restrictionmapper.org/). For each group, the restriction enzymes proposed for use as markers were selected based on their potential ability to differentiate between protected and commercial species. The main criterion was that any candidate enzyme would have restriction sites either for the protected or the commercial group. This 'digest/non-digest' pattern may reveal unambiguous evidence of illegal trade. For the cases in which the enzymes did not generate this 'digest/non-digest' pattern between protected and commercial species, they were still considered suitable markers when the differences in the expected fragments (band sizes) were distinct between protected and commercial groups.

\section{Restriction enzymes used for in silico digestion of $\mathrm{DNA}$ sequences}

AarI, AatII, $A b s \mathrm{I}, A c c \mathrm{I}, A c l \mathrm{I}, A c y \mathrm{I}, A f l \mathrm{II}, A f l \mathrm{III}, A g e \mathrm{I}, A g s \mathrm{I}, A j u \mathrm{I}, A l f \mathrm{I}, A l o \mathrm{I}, A l w \mathrm{NI}$, ApaI, ApaLI, ApoI, ArsI, AscI, AsuII, AvaI, AvaII, AvrII, BaeI, BalI, BamHI, BarI, BbvCI, $B b v \mathrm{I}, B c c \mathrm{I}, B c g \mathrm{I}, B c i \mathrm{VI}, B c l \mathrm{I}, B d a \mathrm{I}, B f i \mathrm{I}, B g l \mathrm{I}, B g l \mathrm{II}, B p l \mathrm{I}, B p u 10 \mathrm{I}, B s a \mathrm{AI}, B s a \mathrm{BI}, B s \mathrm{XXI}$, $B s e \mathrm{MII}, B s e \mathrm{PI}, B s e$ RI, BseSI, BseYI, BsgI, BsmAI, BsmI, $B s p 1407 \mathrm{I}, B s p \mathrm{HI}, B s p \mathrm{MI}, B s r \mathrm{BI}$, BsrDI, BsrI, BstEII, BstXI, BtgZI, BtrI, BtsI, Cfr10I, CfrI, ClaI, Csp CI, DraII, DraIII, DrdI, Eam1105I, EciI, Eco31I, Eco47III, Eco57I, Eco57MI, EcoNI, EcoP15I, EcoRI, EcoRII, EcoRV, Esp3I, FalI, FauI, FokI, FseI, FspAI, GsuI, HaeII, HaeIV, HgaI, Hin4I, HindII, HindIII, HpaI, HphI, Hpy99I, KpnI, MauBI, MboII, MfeI, MluI, MmeI, MsII, NaeI, NarI, NcoI, NdeI, NheI, NmeAIII, NotI, NruI, NspI, OliI, PacI, PasI, PflMI, PfoI, PI-PspI, PI-SceI, PleI, PmaCI,PmeI, PpiI, PpuMI, PshAI, Psi I, PspXI, PsrI, PstI, PvuI, PvuII, RsrII, SacI, SacII, SalI, SanDI, SapI, ScaI, SduI, SexAI, SfaNI, SfiI, SgfI, SgrAI, SgrDI, SmaI, SmlI, SnaBI, SpeI, SphI, SrfI, Sse8387I, SspI, StuI, StyI, SwaI, TaqII, TatI, TauI, TfiI, TseI, TsoI, Tsp45I, TspDTI, TspGWI, TspRI, TstI, Tth111I, VspI, XbaI, XcmI, XhoI, XhoII, XmnI.

\section{RESULTS}

Five restriction enzymes to distinguish between protected and commercial angelshark species were identified. These species were distinguished based on a digested/non-digested pattern. Four enzymes recognized restriction sites on the sequences obtained from the protected $S$. guggenheim and $S$. occulta. In contrast, only one enzyme recognized a restriction site on the sequence of the commercial (trade allowed) S. argentina (Table 2). Overall, these digestions generated expected fragments sizes with lengths between 126 and 354 bp (average of $240 \mathrm{bp}$ ). 
Table 2. Angelshark group's expected or theoretical profile.

\begin{tabular}{|c|c|c|c|c|c|c|}
\hline \multirow[t]{3}{*}{ Restriction enzymes } & \multicolumn{6}{|c|}{ Capture and trade status/Species } \\
\hline & \multicolumn{2}{|c|}{ Commercial/Squatina argentina } & \multicolumn{2}{|c|}{ Protected/Squatina guggenheim } & \multicolumn{2}{|c|}{ Protected/Squatina occulta } \\
\hline & Restriction site & $\begin{array}{l}\text { Expected band } \\
\text { sizes (bp) }\end{array}$ & Restriction site & $\begin{array}{l}\text { Expected band } \\
\text { sizes (bp) }\end{array}$ & Restriction site & $\begin{array}{l}\text { Expected band } \\
\text { sizes (bp) }\end{array}$ \\
\hline BstXI & 217 & 310,170 & Not digested & - & Not digested & - \\
\hline BsgI & Not digested & - & 235 & 327,153 & 235 & 327,153 \\
\hline Bsp MI & Not digested & - & 257 & 349,131 & 257 & 349,131 \\
\hline$B s r \mathrm{DI}$ & Not digested & - & 254 & 343,137 & 254 & 343,137 \\
\hline HaeII & Not digested & - & 34 & 126,354 & 34 & 126,354 \\
\hline
\end{tabular}

Characterization of the restriction sites and expected PCR-RFLP fragment sizes obtained with five restrictions enzymes after in silico digestion of DNA sequences (362 positions) from the mitochondrial gene cytochrome $b$ (cyt $b$ ) of three species of angelsharks from the southern coast of Brazil. Restriction site number refers to nucleotide position in cyt $b$. Expected band size estimated considering an amplicon size of $480 \mathrm{bp}$.

For eyeball amulet group, six restriction enzymes to distinguish between protected and commercial species were identified. Three restriction enzymes recognized restriction sites on sequences from the protected species $S$. guianensis. One enzyme recognized a restriction site only on the sequences obtained from the commercial species $S$. scrofa (domestic pig). Finally, two enzymes recognized restriction sites specific for the remaining commercial species, O. aries (domestic sheep) (Table 3). The expected sizes of the digested fragments varied from $32-427 \mathrm{bp}$ (average of $202 \mathrm{bp}$ ). Finally, the four haplotypes of the river dolphin S. fluviatilis, included in this study for reference purposes, showed the same profile as that obtained for $S$. guianensis (Table 3).

Table 3. Eyeball amulet group's expected or theoretical profile.

\begin{tabular}{|c|c|c|c|c|c|c|}
\hline \multirow[t]{3}{*}{ Restriction enzymes } & \multicolumn{6}{|c|}{ Capture and trade status/Species } \\
\hline & \multicolumn{2}{|c|}{ Protected/Sotalia guianensis (Dolphin) } & \multicolumn{2}{|c|}{ Commercial/Sus scrofa (Pig) } & \multicolumn{2}{|c|}{ Commercial/Ovis aries (Sheep) } \\
\hline & Restriction site & $\begin{array}{l}\text { Expected band } \\
\text { sizes (bp) }\end{array}$ & Restriction site & $\begin{array}{l}\text { Expected band } \\
\text { sizes (bp) }\end{array}$ & Restriction site & $\begin{array}{l}\text { Expected band } \\
\text { sizes (bp) }\end{array}$ \\
\hline ApoI & 57 & 146,334 & Not digested & - & Not digested & - \\
\hline BtsI & 338 & 427,53 & Not digested & - & Not digested & - \\
\hline HindII & 183 & 272,208 & Not digested & - & Not digested & - \\
\hline BsaAI & Not digested & - & 183 & 344,136 & Not digested & - \\
\hline$B p l \mathrm{I}$ & Not digested & - & Not digested & - & 302,334 & $391,32,57$ \\
\hline SspI & Not digested & - & Not digested & - & 42,230 & $131,188,112$ \\
\hline
\end{tabular}

Characterization of the restriction sites and expected PCR-RFLP fragment sizes obtained with six restrictions enzymes after in silico digestion of DNA sequences ( 365 positions) from the mitochondrial gene cytochrome $b$ (cyt $b$ ) of three species known to be involved in the trade of eyeball amulets in northern Brazil. Restriction site number refers to nucleotide position in cyt $b$. Expected band size estimated considering an amplicon size of $480 \mathrm{bp}$.

\section{DISCUSSION}

Here we describe prospective cyt $b$ PCR-RFLP markers for identifying protected species that are illegally traded in Brazil as angelshark carcasses and 'dolphin' eyeball amulets. In addition, this is the first study to deposit in GenBank cyt $b$ sequences for the three angelshark species present off the southern coast of Brazil (S. argentina, S. guggenheim, and S. occulta). Moreover, the $S$. argentina haplotype was the first DNA sequence material of any genomic region for this species to be deposited in GenBank. 
The following aspects confirm the validity of the methods used in the present study for identifying prospective markers. All species known to belong to the trade groups studied (i.e., angelshark carcasses and eyeball amulets) were included in the analyses. Most proposed markers were based on a digest/non-digest pattern that may be used to distinguish between protected and commercial species. In addition, these markers are based on expected band sizes that are easy to visualize by gel electrophoresis.

The number of restriction enzymes found to generate the prospective RFLP markers appears to be sufficient for accounting for intraspecific variation. Mutations naturally found in populations may, in relation to the DNA sequences analyzed, 'erase' or 'generate' restriction sites. This could result in experimental profiles differing from the expected or theoretical results. However, since five and six restriction enzymes were identified for each group studied, the chance that mutations would simultaneously impact all or most of the expected profiles may be considered low. For instance, in a study of felids and canids, $91 \%$ of the expected restriction sites were observed on experimental profiles (Mukherjee et al., 2010). Still, it is suggested that experimental tests should be conducted before implementation of the proposed PCR-RFLP protocols.

\section{Conservation implications}

Investigations of the trade of protected angelsharks and dolphin S. guianensis in Brazil may benefit from the identified sets of prospective molecular markers. Carcasses or complete specimens of angelsharks from southern Brazil can be identified via cyt $b$ PCR and digestion by five restriction enzymes (BstXI, $B s g \mathrm{I}, B s p \mathrm{MI}, B s r \mathrm{DI}$, and HaeII). Importantly, this technique should be used to identify carcasses or any piece known to belong to an angelshark species. Fish fillet or similar meat simply labeled as 'angelshark' ('cação-anjo') may belong to other untested fish species.

For eyeball amulet trade in northern Brazil, species identification can be conducted using cyt $b$ PCR followed by digestion with six restriction enzymes (ApoI, BtsI, HindII, $B s a \mathrm{AI}, B p l \mathrm{I}$, and $S s p \mathrm{I})$. Sotalia guianensis and $S$. fluviatilis have the same expected profiles. Therefore, the proposed PCR-RFLP protocol can be used to identify Sotalia at the genus level. Nevertheless, this has no practical limitation because all cetacean species are protected in Brazil (capture and trade are prohibited). Therefore, the simple detection of Sotalia sp in eyeball amulet tissue samples is sufficient to characterize an illegal trade.

Finally, the PCR-RFLP method proposed in the present study may also be further useful for identifying eyeball amulets because it is based on a small PCR amplicon size. The amulets are dry tissue and may mostly generate poor quality or fragmented genomic DNA. Under such conditions, amplifying a smaller region by PCR increases the probability that the PCR amplification will be successful. In a previous study (Gravena et al., 2008), it was not possible to PCR amplify and generate DNA sequences from some tissue samples, likely because of poor quality or fragmented DNA template. PCR amplicons obtained by Gravena et al. (2008) sized between 500-700 bp. Because the PCR-RFLP identification protocol proposed in the present study is based on the PCR amplification of a smaller fragment ( 480 bp), the chances of successful amplification of a poor quality or fragmented DNA template are increased.

\section{ACKNOWLEDGMENTS}

We thank Ana Paula B. Moreira for helping to build and deposit the submission file at 
GenBank. Coordenação de Aperfeiçoamento de Pessoal de Nível Superior (CAPES, Brazilian Ministry of Education) provided a Postdoctoral fellowship to V.V. Faria (Programa Nacional de Pós-Doutorado - PNPD). The authors are grateful to Antônio M. Solé-Cava and Fernando F. Mendonça for insightful comments on this research during L.H.O. Falcão's poster presentation at IV Congresso Brasileiro de Biologia Marinha (May 2013).

\section{REFERENCES}

Bornatowski H, Braga RR and Vitule JR (2013). Shark mislabeling threatens biodiversity. Science 340: 923.

Cunha HA, Silva VMF, Lailson-Brito Jr J, Santos MCO, et al. (2005). Riverine and marine ecotypes of Sotalia dolphins are different species. Mar. Biol. 148: 449-457.

Diário Catarinense (2013). Pesca Ilegal de Cação-anjo Resulta em Multa de mais de R\$ 1 milhão em Laguna. Available at [http://diariocatarinense.clicrbs.com.br/sc/geral/noticia/2013/08/pesca-ilegal-de-cacao-anjo-resulta-em-multa-demais-de-r-1-milhao-em-laguna-4235314.html]. Accessed February 4, 2014.

Espiñeira M, Vieites JM and Santaclara FJ (2009). Development of a genetic method for the identification of salmon, trout, and bream in seafood products by means of PCR-RFLP and FINS methodologies. Eur. Food Res. Tech. 229: 785-793.

Furtado-Neto MAA (1998). Molecular Systematic and Population Genetics of Marine Vertebrates from Brazil. Doctoral thesis, Memorial University of Newfoundland, St. John's.

Furtado-Neto MAA and Carr SM (2002). Molecular genetics of some Brazilian sharks. SharkNews 14: 10.

G1 (2013). Tipo de Tubarão em Extinção é Apreendido em São Sebastião. G1 Vale do Paraíba e Região. Available at [http://g1.globo.com/sp/vale-do-paraiba-regiao/noticia/2013/09/tipo-de-tubarao-em-extincao-e-apreendido-em-saosebastiao.html]. Accessed February 4, 2014.

Gravena W, Hrbek T, Silva VMF and Farias IP (2008). Amazon River dolphin love fetishes: from folklore to molecular forensics. Mar. Mam. Sci. 24: 969-978.

Irwin DM, Kocher TD and Wilson AC (1991). Evolution of the cytochrome b gene of mammals. J. Mol. Evol. 32: 128-144.

Mendonça FF, Hashimoto DT, Porto-Foresti F, Oliveira C, et al. (2009). Identification of the shark species Rhizoprionodon lalandii and R. porosus (Elasmobranchii, Carcharhinidae) by multiplex PCR and PCR-RFLP techniques. Mol. Ecol. Resour. 9: 771-773.

Mukherjee S, Cn A, Home C and Ramakrishnan U (2010). An evaluation of the PCR-RFLP technique to aid molecularbased monitoring of felids and canids in India. BMC Res. Notes 3: 159.

Sholl TGC, Nascimento FF, Leoncini O, Bonvicino CR, et al. (2008). Taxonomic identification of dolphin love charms commercialized in the Amazonian region through the analysis of cytochrome b DNA. J. Mar. Biol. Assoc. U. K. 88: 1207-1210.

Swofford DL (2000). PAUP* Phylogenetic Analysis Using Parsimony (*and Other Methods). Version 4.02b. Sinauer Associates, Sunderland.

Tamura K, Peterson D, Peterson N, Stecher G, et al. (2011). MEGA5: molecular evolutionary genetics analysis using maximum likelihood, evolutionary distance, and maximum parsimony methods. Mol. Biol. Evol. 28: 2731-2739. 